\title{
The Impact of Foreign Direct Investment on Economic Diversification: The Case of the Republic of Congo
}

\author{
Jean Anaclet Mampassi*, Lauric Ngouembe, Grâce Fleurbellia Domba Biongo \\ Marien Ngouabi University of Brazzaville and Lares \\ Corresponding author: Jean Anaclet Mampassi : mampassianaclet@gmail.com
}

Received: 23February 2021;

Accepted: 03March 2021;

Published: 17 March 2021

\begin{abstract}
The objective of this work is to examine the effects of foreign direct investment on the diversification of the Congolese economy. The estimation results from the ARDL process, spanning the period 1995 to 2016, showed that FDI is a means of diversifying the Congolese economy in the short term. In the long term however, FDI is not a sufficient factor for the diversification of the Congolese economy. Thus, this research has revealed the importance of integrating political stability given that the effects of FDI on diversification also depend on the quality of the institutions.
\end{abstract}

Keywords: foreign direct investment, diversification, ARDL process

JEL classifications : F63 ; P33 ; 055

\section{Introduction}

According to the international trade dictionary, foreign direct investment (FDI), also called international direct investment (IDI) according to the OECD (Organisation for Economic Co-operation and Development), is the international movement of capital with a view to creating, developing or maintaining a foreign subsidiary and/or exercising control (or significant influence) over the management of a foreign enterprise.

FDI is measured in terms of stocks and flows. The stock of inward FDI is an estimate of the total value of capital in a country at a given point in time, while the flow of inward FDI represents the sum of reinvested earnings locally by multinational firms (Ndjambou, 2013). In this work, inward FDI flow is preferred given that it is in continuous movement over a given period of time.

Economic diversification is defined as a process of structural transformation of an economy that shifts from an economic fabric dominated by primary sectors (natural resources, agriculture, mining) towards secondary (processing industries, manufacturing) and tertiary sectors (trade, tourism) (Schuh and Barghouti, 1988; Barghouti et al, 1990; Petit and Barghouti, 1992).

Since the second half of the twentieth century, the acceleration of world trade has been accompanied by an equally rapid change in the structure of trade compared to that predicted by classical trade theories based on perfect competition, comparative advantages and constant returns to scale (Krugman, 1980).

In general, investment is analysed on the basis of three theoretical constructs: public investment (PI), domestic private investment and foreign direct investment (FDI). The latter would constitute one of the levers of the internationalization of multinational companies and its contribution would be essential to boost economic growth, employment, balance of payments and technology transfers. It offers these multinationals, on the one hand, the opportunity to acquire new markets and, on the other hand, gives host countries access to technology transfers and managerial know-how. This can ultimately lead to productivity gains in the local company.

However, during the same period, there are major difficulties encountered by economies dependent on a small number of commodities that are sensitive to the volatility of export prices for these commodities. This dependence can hinder a country's growth and development. The diversification of production and exports can be a foundation for sustainable growth, ensuring stability in the socio-economic development process of countries.

The obvious problem is to know the nature (positive or negative) of the effects of FDI on economic diversification. In order to address this issue, we will first of all present a review of the economic literature (theoretical and empirical). Then, we will set out the stylized facts relating to the development of FDI and export diversification in the Republic of Congo; and lastly conclude by modeling these stylized facts and estimating the model as well as interpreting the results.

\section{Economic literature review}

Since the origin of political economy, the question of its insertion into the international economy has been at the center of the divisions between economists regarding the choice of strategies to achieve this: on the one hand, we have the theories of economic 
diversification or import-substitution (diversified growth) and, on the other hand, the theories of specialization and the international division of labour (unbalanced growth). The issue of the role of foreign direct investment (FDI) arises in all cases with great acuity.

The theoretical literature highlights the hypotheses from two opposing points of view depending on the positive or negative nature of the effects of FDI on the structure of an economy. These various explanations reflect the diversity and inconsistency of the parameters within which direct investments are made in practice.

At the theoretical level, the economic literature reveals two major opposing points of view. In the same way at the empirical level, where verifications of the relationship between FDI and economic diversification are not unambiguous (Moussir and Tabit, 2016; and de Jayaweera, 2009).

\section{i. Theoretical literature}

The first point of view is that FDI is plays a determinant role in the economic diversification of host countries: there would be a positive relationship concerning their effects on the degree of diversification and sophistication of exported products (Harding, T. \& Javorcik, B.S, 2007). From the second point of view, these effects would only be indirect (through the diffusion of spillover effects) and/or negative (increased dependence), particularly in countries exporting cash products (Moussir and Tabit, 2016; and Jayaweera, 2009).

With regard to the "optimistic" point of view, there are two groups of approaches. First, the initial approaches of the 1960s such as the neo-classical theory of capital movements - which focused primarily on the assumptions of market imperfection and international credit differentials, with the potential for higher returns on investment. According to Thomas A. Zimmermann (2008), in industrial economics, direct investments are mainly seen as instruments for exploiting a firm's monopolistic advantages abroad (for example, knowledge).

In addition, he continues, product life cycle theory is another concept that defines FDI as a form of production overseas of products that mature in the home country. In other words, this is a strategy which makes the host country of FDI a country of reexport to the country of origin of these products.

One of the assumptions here is that trade openness helps develop domestic competition, attracts foreign direct investment, facilitates the diffusion of technology, and promotes the learning process and economies of scale. It shows the main role FDI plays through its implications in the discovery of new methods and new products as well as the change in the technological content of exports

One of the objectives also is the conquest of new markets in the sub-region, and subsidiaries of multinational companies established in the host country must be able to compete with local companies. Thus, FDI modifies the export specialization of the host country through the contribution and dissemination of the competitive advantages of the subsidiaries of multinational firms. Other approaches present FDI as the consequence of a strategy or a desire to diversify risk

Finally, the currently dominant "eclectic" paradigm of John H. Dunning ("OLI paradigm", 1980) integrates several theoretical approaches to explain direct investment. According to the author, the volume, geographical distribution and international structure of the production activities (direct investments) of a multinational company depend on the combination of three main factors (Dunning J. H., 2001):
- the specific advantages of the company $(\mathrm{O}=$ Ownership): intellectual capital, capacity for innovation, know-how, strategic capacity;

- the location advantages offered by the host countries (L = Location): human and natural resources, factor endowments and factor costs, taxation, government collaboration;

- the advantages of internalizing transactions within the company $(\mathrm{I}=$ Internalization $)$ : transaction costs, knowledge transfer risk, etc.

Regarding the second point of view, world systems theory posits that the countries of the South cannot transform themselves because of unequal relations in terms of trade (Wallerstein, 1975). International trade induced by a division and/or specialization of labour gives rise to an international structure of nation-states with unequal power and allows for an accelerated accumulation process in the core countries. These unequal economic relations reinforce the cycle of backwardness in peripheral countries. This argument sheds light on why African economies are also capitalist, because the world system is capitalist. The economic and political problems of the South are perceived as resulting from the structural contradictions of the capitalist economy.

In the same vein, dependency theory suggests that the socioeconomic foundations of a society are indispensable for understanding its development process. The argument put forward here is that the increased participation of Third World companies in the global economy results in the disintegration of their economies by widening the gap between rich and poor in the international system due to structural differences. Through international trade, foreign direct investment, foreign debt and foreign aid, industrialized societies link up with Third World societies. This link will lead not only to an economic dependence of the Third World on the industrialized countries, but also to a transfer of resources (human and material). The consequence is the appearance of distortions in the development process (Akpotor, 2000; Odion, Agbebaku and Kadiri, 2013).

More recent theoretical approaches to non-beneficial effects, think that FDI through multinational firms leads to spillover effects to local firms through the transfer of productive capacities. According to Moussir and Tabit (2016), this transfer of capacities does not necessarily lead to export diversification; for even if it is successfully achieved, national firms will be reluctant to embark on new production because of considerable uncertainty about the local profitability of investments and the existence of "discovery costs" (Hausmann and Rodrik, 2003). In other words, when the cost of entering a new market becomes too high, new goods will not be produced even when the host country has all the necessary capacity (Iwamoto and Nabeshima, 2012). Thus, FDI may not be beneficial to the development of the local economic fabric. Also, Kokko (1996) believes that the strong presence of multinational corporations can lead to industrial concentration and lead to monopolies in some markets that were previously oligopolistic.

\section{ii . Empirical Literature}

At the empirical level, the literature review identified numerous works that have led to highly controversial results. The empirical studies of Harding, T. \& Javorcik, B.S., 2007, de Banga (2006), de Dunning (1988), de Kojima (1973), de Mucchielli (2002), d'Alemu (2008), de Jayaweera (2009), de Tadesse and Shukralla (2013), de Moussir and Tabit (2016) corroborate this controversy in a relatively perceptible way. 
Firstly, a study conducted on nine Central and Southern European countries shows empirically that there is a positive relationship between FDI and export diversification of host countries (Harding, T. \& Javorcik, B.S, 2007), through the influence of FDI on the degree of sophistication of exported products. Banga (2006), meanwhile, assesses the impact of U.S. and Japanese FDI on export diversification in the Indian manufacturing sector and finds that U.S. FDI flows to India have a statistically significant positive impact on the intensity of the Indian manufacturing exports.

Using Feasible Generalized Least Squares (FGLS) estimation methods with corrected heteroscedasticity and autocorrelation, Alemu (2008) analyzes the main determinants of vertical and horizontal diversification of exports in 41 countries in Sub-Saharan Africa and East Asia over the 1975-2004 period. He concludes that FDI is a determinant of the process of accelerating vertical and horizontal export diversification in East Asia.

Similarly, using parametric and semi-parametric methods, Tadesse and Shukralla (2013) examine the effect of FDI on the horizontal diversification of exports in 131 countries spanning the years 1984 to 2004, and the results turn out to be positive. Jayaweera (2009) uses an estimation technique of instrumental variables on a panel of 29 low-income countries between 1990 and 2006, and he observes a positive relationship between increased FDI and increased export diversification. Moussir and Tabit use the Generalized Method of Moments (GMM) and reach the same conclusions in a study on Morocco (2016).

However, most of these studies, depending on the country context or on the type and stock of FDI and its sources, demonstrate the opposite effects. For example, Banga (2006) shows that Japanese FDI, unlike those of American origin, have an insignificant impact on Indian exports. Similarly, Bebczuk and Berrettoni (2006) found no statistically significant effect of FDI on export diversification on a panel of 56 countries spanning the years 1962 to 2002.

We also observe, with regard to Sub-Saharan Africa, that Alemu's (2008) study concludes that FDI have a negative impact on horizontal diversification. Also, Jayaweera (2009) shows that the relationship between increased FDI and increased export diversification becomes negative for countries that export a high proportion of oil and mining resources. In their study, Tadesse and Shukralla (2013) also find that the effect of FDI on horizontal export diversification varies according to the stock of FDI and the stage of diversification of each country.

Arawomo et al (2014) have shown that FDI discourages export diversification in Nigeria. For his part, Kamuganga (2012) studies the different determinants of export diversification in Africa for the period 1995-2009. He concludes that FDI has a negative effect.

From the above, the review of the theoretical and empirical literature calls for some comments. There is a lack of uniformity of views at the theoretical level as long as some focus on the possible positive effects inherent in the influx of FDI while others find negative effects and the way to establish an unequal relationship or dependency between countries of the North and those of the South. The various empirical analyses are inconclusive in settling the theoretical debate insofar as the effects of FDIs are not linear. They depend on a number of factors, including the undiversified or nondiversified nature of the economic base of host countries, their factor endowment, the quality of their governance, etc. The effects of FDIs are not linear.

Therefore, the central question is whether FDI contributes to export diversification and product sophistication? It is important to examine this issue in the context of African countries such as the Republic of Congo, which has a poorly diversified economy, highly dependent on primary resources (oil). Moreover, the country is experiencing difficulties in governance.

The rest of the paper is organized in three parts: the first part is devoted to presenting the stylized facts of the Congolese economy; the second develops the modeling of the effects of FDI on the diversification of the Congolese economy and the estimation of the model; and the third is concerned with the interpretation of the estimated results.

\section{Stylised facts}

The Congolese economy essentially relies on the exploitation of natural resources, particularly oil. According to the United Nations Development Programme (UNDP, 2012), oil accounts for more than $70 \%$ of the gross domestic product and gross fixed capital formation, more than $90 \%$ of exports and more than $80 \%$ of state revenue. The high concentration of exports on oil makes the economy vulnerable to price or demand shocks for this raw material.

The perpetuation of this economic hypertrophy leads us to the hypothesis that FDI has no real and direct effects on the diversification of the Congolese economy. In other words, in countries such as the Republic of Congo (primary type specialization) FDI are concentrated in mining, oil and, somewhat, in agricultural activities.

Our aim in this section is to take stock of the FDI situation, on the one hand, and the state of economic diversification in the Congo, on the other. Above all, however, it is preferable to elucidate each key concept of our study in the above-mentioned subsections in order to better assimilate them.

\section{Global growth and concentration of FDI in Congo}

Since 1980, and despite the turmoil of the 1990s, the Congolese economy has continued to benefit from FDI inflows. From 2009 to 2014, FDI inflows rose from US\$ 1,274 million in2009 to US\$ 5,502 million in 2014 (UNCTAD, 2015); an increase of US\$ 705 million on average per year. The volume (in value) of FDI received by Congo was higher than that of other countries in the Central African Economic and Monetary Community - CEMAC (see Figure 1). At the end of 2012, the Republic of Congo was ranked 8th largest FDI host country on the entire African continent in terms of stock, the 3rd out of 48 countries in sub-Saharan Africa after South Africa and Nigeria and by far the 1st in Central Africa .

The main investors in the Republic of Congo are France, which is active in the oil sector, services and agro-industry; China in cement and wood; Italy in oil, timber and gold; the United States, whose activities are concentrated in the oil sector, flour milling and tobacco; the Netherlands in brewing and Germany in timber. The bulk of these investments, both in terms of inflows and stocks, is more directed towards the oil sector. However, the country has difficulty attracting FDI in other sectors due to the poor business climate.

The figure below shows the growth of FDI inflows to Congo as compared to those of other CEMAC countries from 1980 to 2016. When analysing the graph, it was noticed that from 1980 to 2008 , these countries benefited from a low proportion of FDI overall, but from 2008 to 2016, only Congo and Equatorial Guinea received a large share of FDI with a record level of US\$ 5,502 million for Congo and US\$2,734 million) for Equatorial Guinea in 2014 and 2010 respectively. 
Figure 1: Growth of FDI inflows (in million USD) in the CEMAC zone

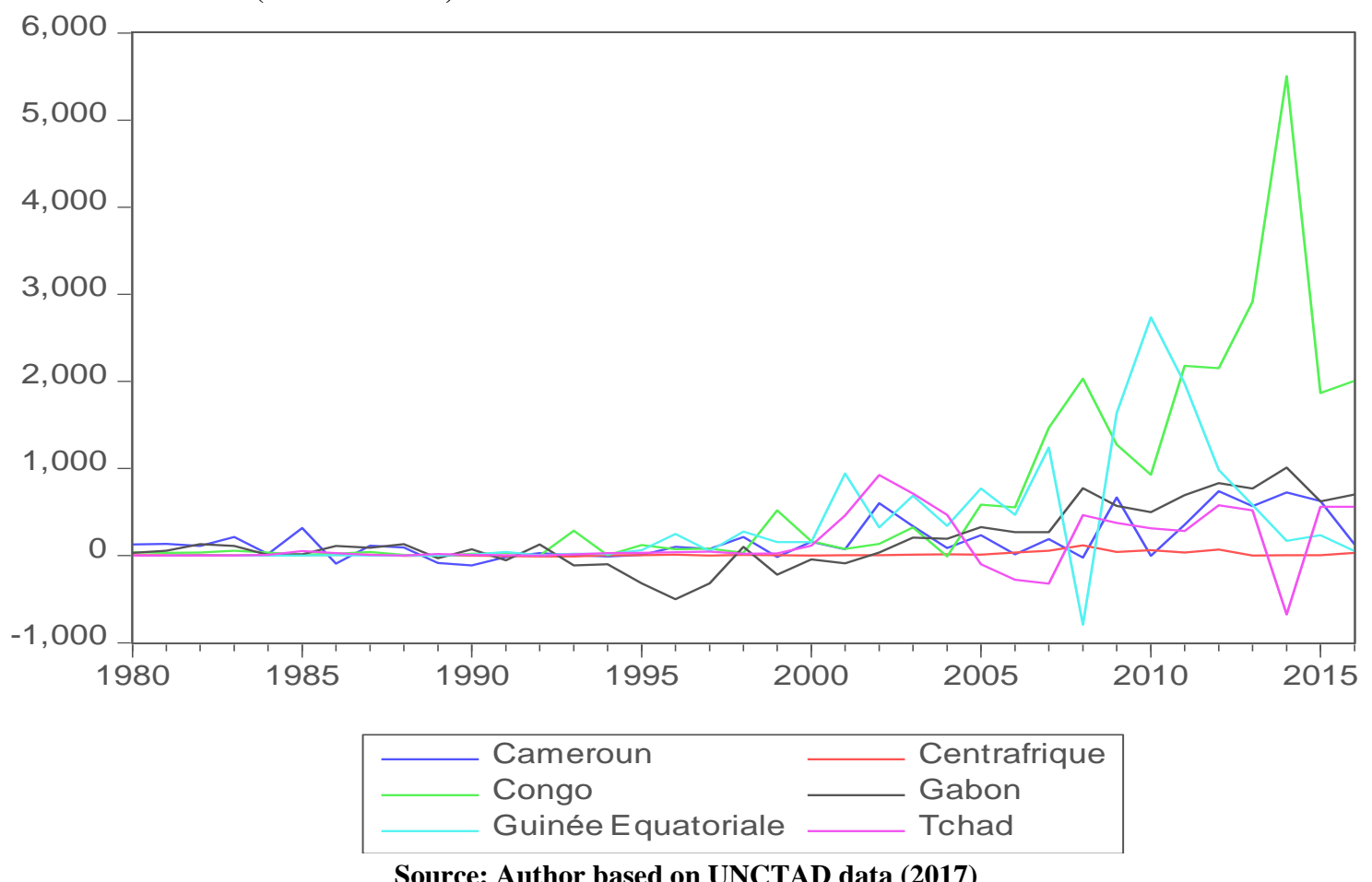

Source: Author based on UNCTAD data (2017)

\section{i. Evolution of the diversification situation in Congo}

The diversification of economic activities in the Republic of Congo is a major concern to reduce the vulnerability of the Congolese economy to external shocks and the risks associated with the economy's excessive dependence on oil.

To address this dependence, the Congolese government has integrated diversification into many of its national development plans but without success. Moreover, the last national development plan(PND) for the period 2018-2022, which emanates from the PND for the period 2012-2016, places the diversification process at the core of development activities.

This new PND also aims to diversify the economy but focusing more on the agriculture, forestry and industry sectors. This strategy stems from the difficulties encountered in preparing development programmes that focus on accelerating diversification and reducing imports to save foreign exchange reserves. The main challenge faced is the oil crisis followed by its spillover effects on the overall economy and the State budget. In this respect, agriculture and forestry are growth-enhancing sectors where Congo has undeniable competitive advantages, and can generate income for a large part of the population, especially the rural population.

Centering diversification on these two components will help the economy to be less dependent on oil shocks. This diversification can only be possible if the private sector participates in it in an unquestionable manner. Congo must therefore imperatively improve its business climate to provide a motivating and stimulating framework for private initiative in order for this to happen. An assessment of the PND (2012-2016) revealed that the performance achieved in terms of economic diversification has fallen far short of the expected objectives. Indeed, the increased industrialization integrated into this plan has not been achieved. Throughout the 2012-2016 period, the share of non-extractive industries in non-oil GDP remained relatively stable. Consequently, from 2014 to 2015 the Congolese economy deteriorated as a result of the oil crisis that the country went through. This deterioration has confirmed a weakness in diversification and a persistent dependence of the economy and government revenues on the oil sector. On this basis, the table below shows the structure of the GDP:

Table 1: Structure of GDP (\%)

\begin{tabular}{|l|l|l|l|l|}
\hline & 2012 & 2013 & 2014 & 2015 \\
\hline $\begin{array}{l}\text { Agriculture, livestock, } \\
\text { hunting and fishing }\end{array}$ & 3.6 & 4.1 & 4.7 & 7.0 \\
\hline Silviculture and logging & 0.3 & 0.3 & 0.3 & 0.4 \\
\hline Extractive industries & 67.0 & 63.1 & 59.3 & 39.6 \\
\hline Secondary sector & 7.8 & 8.8 & 9.9 & 14.8 \\
\hline Tertiary sector & 19.4 & 21.7 & 23.5 & 34.8 \\
\hline Import duties and taxes & 1.9 & 2.1 & 2.3 & 3.4 \\
\hline
\end{tabular}

Source: National Institute of Statistics, National Accounts (2015)

After an overview of diversification in the Congo, we thought it would be useful to present a graph to observe the changes in the concentration index in CEMAC countries and particularly in the Congo. However, it should be noted that in this work, the indicator used is the concentration index since Congo is a country whose activities are concentrated around very few sectors, mostly the oil sector. This index is the Herfindahl-Hirschman index and is calculated as follows:

$\mathrm{HHI}_{\mathrm{t}}=\left(\frac{\sqrt{\sum_{i=1}^{n}\left(\frac{x_{i t}}{x_{t}}\right)^{2}}-\sqrt{1 / n}}{1-\sqrt{1 / n}}\right) \times 100$

Given that $X_{\mathrm{it}}$ : the value of the country's exports for product $\mathrm{i}$ in year $\mathrm{t} ; n$ : the number of products and $X_{\mathrm{t}}$ : the total exports of the country for product $i$ in year $t$.

This index takes values ranging from 0 to 1 . An index value close to 1 indicates that exports are highly concentrated on a few products while a value close to 0 represents a higher degree of 
export diversification. In our study, instead of doing this from the UNCTAD database.

calculation, we will rather retrieve the concentration index data

Figure 2: Evolution of the concentration index in Congo in comparison with that of other CEMAC countries

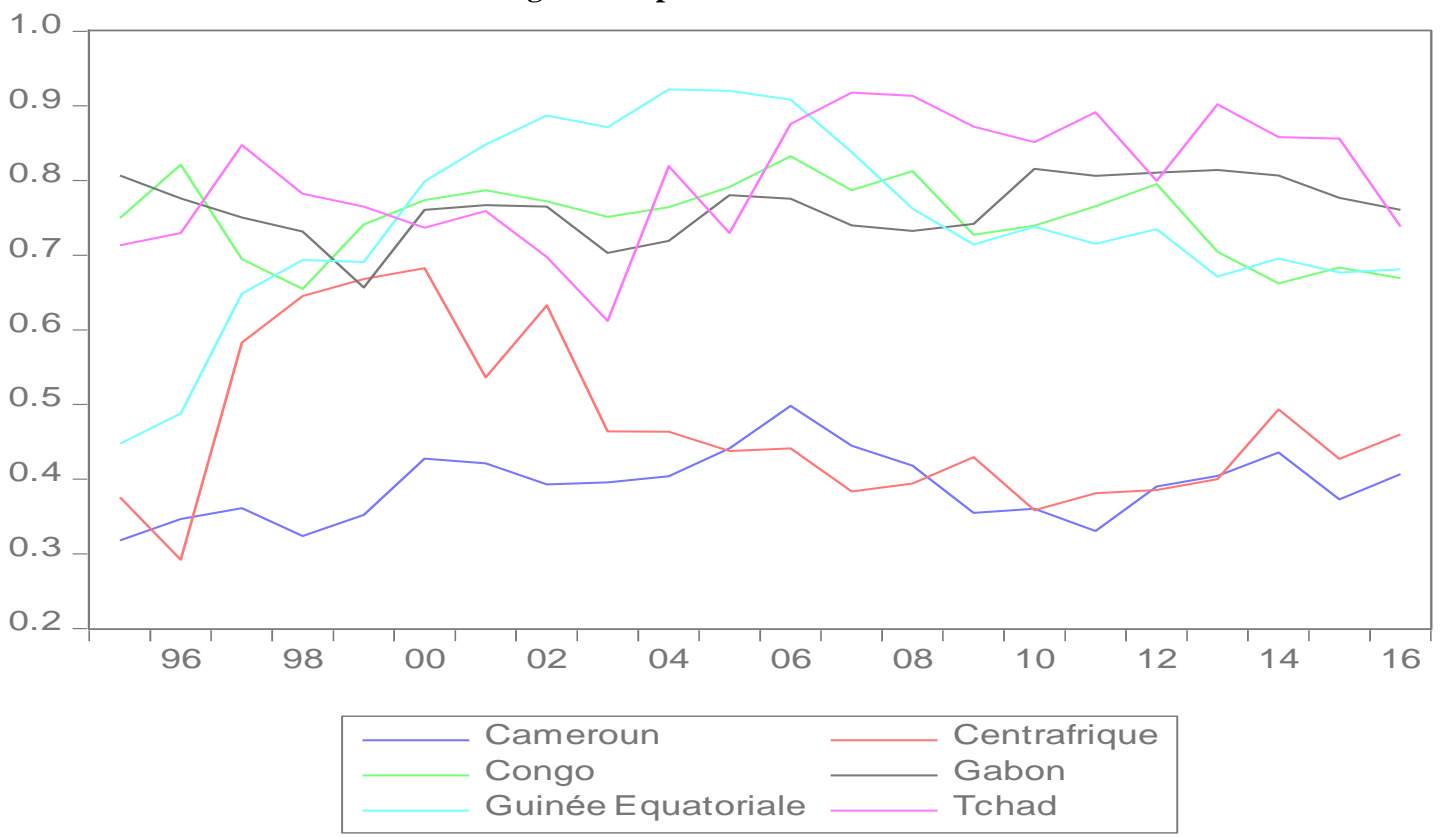

Source: Author based on data from UNCTAD (2017)

The graph above indicates that CEMAC countries have a very high level of concentration, with the exception of Cameroon, which has a low concentration. The Republic of Congo is a highly concentrated country given that its index value is close to unity.

\section{Modelling the effects of FDI on diversification}

To verify our hypothesis, we used an econometric approach by opting for the ARDL technique. The reason for using this technique is due to the small size of our sample, with data spanning from 1995 to 2016. These data are collected from the World Bank database, more precisely the World Development Indicator (WDI, 2017) and from UNCTAD (2017). Since the number of observations does not permit us to make statistical inferences, we had to present the data in quarterly series.

\section{Theoretical and empirical model}

The model used in this study derives from an international trade model developed by Melitz in 2003. It is a model of heterogeneous firms based on two assumptions: the existence of differences in productivity between firms and the differentiation of related products. According to Helpman (2006), Melitz's model is as follows:

Suppose the demand for a particular product is given by:

$X_{i}=A P(i)^{-E}$

Where

$\mathrm{X}_{\mathrm{i}}$ : is the demand for a product of company $\mathrm{i}$

$A:$ is an exogenous component of demand

$\mathrm{P}(\mathrm{i})$ : is the price of the product of company $\mathrm{i}$

E: is a constant elasticity of demand. It is given by $E=1 / 1-\alpha$

where $\alpha$ : is a constant within the range of $[0,1]$

In Melitz's (2003) model, it is possible to show when diversification occurs and how FDI affect diversification both directly and indirectly. In terms of the direct and indirect effects of FDI on diversification, Melitz's (2003) model predicts that FDI have an effect on the three drivers of diversification discussed in this model, namely, changes in productivity density, lower export costs, and changes in factor demand (Jayaweera, 2009; Lamek, 2016). Indeed, FDI can increase export profit opportunities in various sectors through the productivity spillovers channel. FDI have market access spillovers, which means that they have an indirect impact on diversification through market access spillovers. Thus, we are able to write:

$D I V=F(I D E, X)$

Given that DIV= diversification, FDI=foreign direct investment and $\mathrm{X}=$ other factors explaining the diversification of the economy.

Starting from equation (3) and taking into account the degree of openness of the economy (DOE) and the official exchange rate (OER) as variables explaining the diversification of the economy, the theoretical model thus becomes:

$D I V=\beta_{0}+\beta_{1} I D E+\beta_{2} D O E+\beta_{3} T C O$

For estimation purposes, therefore, the econometric model is as follows:

$D I V_{t}=\beta_{0}+\beta_{1} I D E_{t}+\beta_{2} D O E_{t}+\beta_{3} T C O_{t}+\varepsilon_{t}$

Table 2: Expected signs of the different explanatory variables

\begin{tabular}{|l|l|l|}
\hline Variable & Coefficient & Expected sign \\
\hline FDI & $\beta_{1}$ & + \\
\hline DOE & $\beta_{2}$ & - \\
\hline OER & $\beta_{3}$ & + \\
\hline
\end{tabular}

Source: Author

This table summarizes the expected signs of the different explanatory variables of our model according to the theory.

Presentation of variables 
The variables in our model are based on the empirical literature on the subject. We have a dependent variable, a variable of interest and two control variables.

CI: is the concentration index and is the dependent variable in our study. This index measures the sectoral concentration of a country's exports and helps to identify the market structure. This concentration index, which is the Herfinfahl-Hirschman index, has been used as a measure of diversification by many authors such as Alaya (2012), Iwamoto and Nabeshima (2012), Arawomo et al (2014), Moussir and Tabit (2016).

FDI: represents the flow of foreign direct investment and is the variable of interest in our study, expressed in \% of GDP and has been used by many authors such as Iwamoto and Nabeshima (2012), Arawomo et al (2014) and Moussir and Tabit (2016).

OER and DOE have been chosen as control variables to better assess the country's international competitiveness. The official exchange rate is defined as a unit of local currency against the US dollar. An appreciation of the dollar will bring about an increase in international competitiveness, which could lead to export diversification. On the other hand, a depreciation of this rate will slow down the diversification process.

The degree of openness, for its part, is an indicator for measuring a country's foreign trade. It indicates external dependence. Trade openness can play a key role in the diversification process if and only if the country's leaders set aside the main obstacles that hinder business development.

These two variables were used as control variables by Alaya (2012), Moussir and Tabit (2016).

\section{Analysis of the results}

In this section, we will first present our results and then proceed with our analysis.

\section{Presentation of results}

Table 3: Short-term results

\begin{tabular}{|l|l|l|l|l|}
\hline Variable & Coefficient & Stadard deviation & Statistical test & Probability \\
\hline $\mathrm{D}(\mathrm{CI}(-1))$ & 1.305623 & 0.080609 & 16.196928 & 0.0000 \\
\hline $\mathrm{D}(\mathrm{CI}(-2))$ & -0.297346 & 0.130162 & -2.284432 & 0.0256 \\
\hline $\mathrm{D}(\mathrm{CI}(-3))$ & 0.034598 & 0.130583 & 0.264949 & 0.7919 \\
\hline $\mathrm{D}(\mathrm{CI}(-4))$ & -0.552810 & 0.127863 & -4.323442 & 0.0001 \\
\hline $\mathrm{D}(\mathrm{CI}(-5))$ & 0.593157 & 0.083438 & 7.108994 & 0.0000 \\
\hline $\mathrm{D}(\mathrm{FDI})$ & 0.001223 & 0.000352 & 3.469218 & $0.0009^{*}$ \\
\hline $\mathrm{D}(\mathrm{FDI}(-1))$ & -0.001220 & 0.000344 & -3.547128 & $0.0007^{*}$ \\
\hline $\mathrm{D}(\mathrm{OER})$ & 0.000167 & 0.000081 & 2.060183 & $0.0434^{* *}$ \\
\hline $\mathrm{D}(\mathrm{OER}(-1))$ & -0.000289 & 0.000083 & -3.503795 & 0.0008 \\
\hline $\mathrm{D}(\mathrm{DOE})$ & 0.000752 & 0.000305 & 2.464759 & $0.0164^{* *}$ \\
\hline $\mathrm{D}(\mathrm{DOE}(-1))$ & -0.001053 & -2.074746 & 0.0420 \\
\hline $\mathrm{D}(\mathrm{DOE}(-2))$ & 0.000690 & 0.000508 & 2.284848 & 0.0256 \\
\hline CointEq(-1) & -0.066927 & -5.754703 & 0.0000 \\
\hline Cointeq= IC- $\left(0.0030^{*}\right.$ FDI $+0.0001^{*}$ OER $+0.0008^{*}$ DOE +0.1102$)$ & & \\
\hline
\end{tabular}

$* ; * *$ denote the $5 \%$ and $10 \%$ significance levels respectively.

Table4: Long-term results

\begin{tabular}{|l|l|l|l|l|}
\hline Variable & Coefficient & Standard deviation & Statistical test & Probability \\
\hline FDI & 0.003006 & 0.001926 & 1.560943 & 0.1234 \\
\hline OER & 0.000134 & 0.000148 & 0.903865 & 0.3694 \\
\hline DOE & 0.000795 & 0.000600 & 1.324324 & 0.1900 \\
\hline C & 0.110175 & 0.052850 & 2.084682 & 0.0410 \\
\hline
\end{tabular}

\section{Discussion of results}

We can draw two main lessons from the results of the estimation of the ARDL technique. The first lesson highlights the existence of the effects of FDI on diversification in the short term. The second lesson highlights the absence of FDI effects on long-term diversification.

\section{1) The determinism of FDI on the diversification of the} Congolese economy in the short term

A simple reading of the results in Table 3 shows that FDI have mixed effects on diversification in the Republic of Congo. On the one hand, they have negative effects and on the other hand, positive effects.

The negative effects of FDI on economic diversification in the Republic of Congo are captured by the estimation results since the coefficient associated with the FDI variable is positive (0.001223) and significant $(\mathrm{p}=0.0009)$ at the $5 \%$ significance level. The latter suggests a positive change between the two variables, which means they evolve in the same direction; thus a one point change of the FDI rate leads to an increase of 0.0012 point of the concentration index and thus to a low level of diversification. This result corroborates those obtained by Bebczuk and Berrettoni (2006), Jayaweera (2009). The latter argues that the relationship between FDI and diversification is negative in countries that export more oil and mining resources.

Thus, he agrees with the findings of Kamuganga (2012) and Arawomo et al (2014) that FDI has a negative effect on export diversification. Moreover, this result confirms the hypothesis defended in this work that FDI is not likely to promote economic diversification in Congo. The result also corroborates what is 
characteristic of the Congolese economy, which is that it is essentially based on natural resources, particularly crude oil, towards which almost all FDI is directed. Up to $70 \%$ of these FDI are concentrated in the oil sector, thus reinforcing the specialization in oil exports, where it accounts for more than $90 \%$ of total exports.

The positive effects of FDI on the diversification of the economy in the Republic of Congo are assessed on the basis of the table of estimation results in which the coefficient associated with the FDI(-1) variable is negative (-0.001220) and significant $(\mathrm{p}=0.0007)$ at the $5 \%$ significance level. The latter suggests a negative correlation between the two variables. In other words, an increase of one point in the FDI rate at time t- 1 leads to a decrease in the concentration index of 0.0012 point at time $t$, which implies a strong diversification. This result corroborates with those obtained by Banga (2006) in the case of India concerning US FDI, and Moussir and Tabit (2016) in Morocco. Moreover, this result does not confirm the hypothesis defended in this work. This can be explained by recent performance in the services sector (banking and telecommunications) and the extractive industries sector (mining), which have generated a significant level of foreign direct investment. In the 2000 s, with the liberalization of the mobile telephony, the share of the services sector in GDP grew considerably. It rose from $22.54 \%$ to $23.57 \%$ in 2000 and 2005 respectively, to reach $38.08 \%$ in 2015 (WDI, 2017). On the other hand, the share of extractive industries in GDP was $64.1 \%$ in 2005 against $69.8 \%$ in 2010 . In 2015, it dropped to $39.6 \%$ (INS, 2015) following the fall in commodity prices on the international market. Our conclusion is that, in the long run, FDI is not a sufficient determinant of economic diversification in Congo.

2) The lack of influence of FDI on the diversification of the Congolese economy in the long term

Contrarily to short-term results, FDI has no influence on long-term diversification in the Republic of Congo. Indeed, the coefficient associated with the FDI variable is not significant at either the 5\% or $10 \%$ significance level. This is justified because FDI directed into the oil sector has only a statistically insignificant effect on the broadening of the productive base. Oil dominates the production structure of national wealth, foreign trade, public finance, public investment, development financing and Congo's debt. In 2014, it contributed 54.1 percent of GDP. This predominance of hydrocarbons, despite abundant endowments in other natural resources (such as timber and non-timber forest products), reflects the difficulties of the Congolese authorities in undertaking a structural transformation of their economy (UNCA, 2015).

Beyond these results, it is worth emphasising that the control variables have an effect on diversification in the Republic of Congo, particularly in the short term, which avoids a carry-over effect on the variable of interest discussed in the subsections above.

\section{Conclusion and Policy implications}

The objective of this study was to highlight the effects of FDI on economic diversification. To achieve this, quarterly data spanning the period 1995-2016, as well as the ARDL process were used. The results obtained did not confirm the hypothesis of our study. Also, this work has shown that investments in non-oil sectors are negligible.

Thus, policymakers must go further to improve the business climate while developing basic infrastructure to attract private investment targeting the non-oil sectors.

\section{References}

[1] Alaya, M. ed. (2012), The Determinants of MENA Export Diversification: An Empirical Analysis, Working Paper No. 709, Economic Research Forum, 26 p.

[2] Alemu, A.M. (2008), « Determinants of Vertical and Horizontal Export Diversification: Evidences from SubSaharan Africa and East Asia », Ethiopian Journal of Economics, Vol. 17, No. 2, pp. 1-23.

[3] Arawomo, D.F., Oyelade, A.O. and Tella, A.T. (2014), « Determinants of Export Diversification in Nigeria: Any Special Role for Foreign Direct Investment (FDI)? », Journal of Economics and Business Research, Vol. 20, No. 2, pp. 21-33.

[4] Banga, R. (2006), « The Export-Diversifying Impact of Japanese and US Foreign Direct Investments in the Indian Manufacturing Sector », Journal of International Business Studies, Vol. 37, No. 4, pp. 558-568.

[5] Barghouti, S., Timmer, C. and Siegel, P.R. (1990), Rural Diversification: Lessons from East Asia, World Bank Technical Paper No. 117, Washington DC: The World Bank, 132 p.

[6] Bebczuk, R.N. and Berrettoni, N.D. (2006), Explaining Export Diversification: An Empirical Analysis, CAF Research Program on Development Issues, $26 \mathrm{p}$.

[7] Conférence des Nations Unies sur le Commerce et le Développement (2015), Rapport sur l'investissement dans le monde : "Réformer la gouvernance de l'investissement international », Genève, $67 \mathrm{p}$.

[8] Conférence des Nations Unies sur le Commerce et le Développement (2016), Rapport sur l'investissement dans le monde : Nationalité des investisseurs : enjeux et politiques, Genève, $55 \mathrm{p}$.

[9] Dunning, J.H. (1988), « The Eclectic Paradigm of International Production: A Restatement and Some Possible Extensions », Journal of International Business Studies, Vol. 19, No. 1, pp. 1-31.

[10] Hausmann, R. and Rodrik, D. (2003), « Economic Development as Self-Discovery », Journal of Development Economics, Vol. 72, No. 2, pp. 603-633.

[11] Helpman, E. (2006), « Trade, FDI and the Organization of Firms », Journal of Economic Literature, Vol. 44, No. 3, pp. 589-630.

[12] Imbs, J. and Wacziarg, R. (2003), « Stages of Diversification », The American Economic Review, Vol. 93, No. 1, pp. 63-86.

[13] Iwamoto, M. and Nabeshima, K. (2012), Can FDI Promote Export Diversification and Sophistication of Host Countries? Dynamic Panel System GMM Analysis, Institute of Developing Economies Discussion Paper, No. 347,42 p.

[14] Jayaweera, Sh. (2009), Foreign Direct Investment and Export Diversification in Low Income Nations, The 
University of New South Wales, Australian School of Business/ School of Economics.

[15] Kamuganga, D. (2012), What Drives Africa's Export Diversification?, Working Paper No. 15, Graduate Institute of International and Development studies.

[16] Klinger, B. and Lederman, D. (2006), Diversification, Innovation, and Imitation Inside the Global Technological Frontier, World Bank Policy Research Working Paper, 24 p.

[17] Kojima, K. (1973), « A Macroeconomic Approach to Foreign Direct Investment », Hitotsubashi Journal of Economics, Vol. 14, No. 1, pp. 1-21.

[18] Kokko, A. (1996), « Productivity Spillovers from Competition Between Local Firms and Foreign Affiliates », Journal of International Development, Vol. 8, pp. 517530.

[19] Lamek, T. (2016), The Impact of Foreign Direct Investment on Export Diversification: A panel Study on Common Market for Eastern and Southern Africa, Addis-Ababa University, Ethiopia.

[20] Melitz, M.J. (2003), « The Impact of Trade on IntraIndustry Reallocations and Aggregate Industry Productivity », Econometrica, Vol. 71, No. 6, pp. 16951725.

[21] Mucchielli, J.L. (2002), « IDE et exportations : compléments ou substituts ? », Problèmes économiques, 6 March.
[22] Moussir, C.E. and Tabit, S. (2016), « Export Diversification and Structural Transformation in Morocco : What Role for FDI ? », in Equilibres externes, Compétitivité et Processus de Transformation Structurelle de l'Economie Marocaine, OCP Policy Center.

[23] Ndjambou, P. (2013), La diversification économique territoriale au Gabon : Enjeux, déterminants, stratégies, modalités, conditions et perspectives, Université du Québec.

[24] Petit, M. and Barghouti, S. (1992), «Diversification: Challenges and Opportunities ", in S. Barghouti, L. Gaebus et D. Lunali (eds), Trends in Agricultural Diversification: Regional Perspectives, World Bank Technical Paper, Washington DC: The World Bank.

[25] PNUD (2012), Etude sur la vulnérabilité de l'économie congolaise et ses perspectives de diversification, $228 \mathrm{p}$.

[26] Rodrik, D. (2006), «What's So Special about China's Exports? », China and World Economy, Vol. 14, No. 5, pp. 1-19.

[27] Schuh, E. and Barghouti, S. (1988), « Agricultural Diversification in Asia », Finance and Development, Vol. 25, No. 2, pp. 2541-2544.

[28] Tadesse, B. and Shukralla, E.K. (2013), « The Impact of Foreign Direct Investment on Horizontal Export Diversification : Empirical Evidence », Applied Economics, Vol. 45, No. 2, pp. 141-159. 